\title{
Ultrasonographic Diagnosis of Extremity Masses
}

\author{
Ethan M. Braunstein, M.D., Terry M. Silver, M.D., William Martel, M.D., and Mark Jaffe, M.D. \\ Department of Radiology, Divisions of Skeletal Radiology (E.M.B., W.M.) and Ultrasound (T.M.S., M.J.), \\ University of Michigan Medical Center, Ann Arbor, Michigan, USA
}

\begin{abstract}
Radiographic examination of soft tissue extremity masses is frequently inconclusive. In 18 patients with normal or nonspecifically abnormal radiographs, gray scale ultrasonography provided useful additional information. It was possible to distinguish fluid collections from solid masses, and recurrent venous thrombosis from hematoma in anticoagulated patients. Occasionally, specific diagnoses were suggested on the basis of ultrasonic morphologic characteristics. Diagnoses included soft tissue neoplasms, hematomas, aneurysms, synovial cysts, abscesses, and a lymphocele.

Ultrasonically guided percutaneous needle aspiration was diagnostic in two cases. Features of differential diagnostic value relative to extremity solid masses and fluid collections are discussed. Ultrasonography is useful in evaluating these soft tissue masses.
\end{abstract}

Key words: Ultrasonography - Soft tissue masses, extremity.

Gray scale ultrasonography is an established procedure to diagnose intra-abdominal and pelvic disease. However, its role and efficacy in evaluating extremity masses have received less attention [4]. Inasmuch as plain radiographs of masses in the extremities are frequently nonspecific, ultrasonic characterization of the nature and anatomic extent of such masses may facilitate diagnosis and management.

\section{Materials and Methods}

The clinical, radiologic, and ultrasonographic findings in $18 \mathrm{pa}-$ tients in whom ultrasonography suggested a diagnosis not clearly evident on plain radiography were analyzed. The ultrasound exami-

Address reprint requests to: Ethan M. Braunstein, M.D., Department of Radiology, Divisions of Sketetal Radiology, University of Michigan Medical Center, Ann Arbor, MI 48109, USA nations were performed with commercially available gray scale equipment using $3.5,5.0$, or $7.5 \mathrm{MHz}$ internally focused transducers. Additional radiographic modalities included plain radiography in 16 cases, arteriography in four, venography in four, sinography in two, and arthrography in one. All radiographs were reviewed in conjunction with the ultrasonic examination retrospectively to determine if radiographic findings were absent, or present but not initially observed. In two cases, ultrasonically guided percutaneous needle aspiration was performed for diagnosis.

\section{Results}

These cases were categorized as fluid collections or solid masses, and are summarized in Table 1.

\section{Fluid Collections}

In 12 cases, masses were demonstrated to be predominantly fluid filled.

1. Abscesses. All four abscesses had irregular margins. Two contained scattered internal echoes (Fig. 1). In two of the cases, ultrasonically guided percutaneous needle aspiration and culture grew Beta hemolytic streptococci and Escherichia coli, respectively. Plain radiographs demonstrated soft tissue swelling in two of the four cases (Fig. 1), and were normal in two others. In no cases was a discrete mass localized on plain radiographs.

2. Hematomas. The correct diagnosis of hematoma was suggested by ultrasonography in conjunction with clinical history in four cases. In three of these, there were well defined masses with both solid and cystic components (Fig. 2). However, in the fourth case, a totally echo free area surrounded a well defined soft tissue mass, as if a hematoma had dissected around a muscle belly (Fig. 3). Two of the four patients were on warfarin due to deep venous thrombosis. In these patients, ultrasonography, in establishing 
Table 1.

\begin{tabular}{|c|c|c|c|c|c|}
\hline Case & $\begin{array}{l}\text { Age (years) } \\
\text { and sex }\end{array}$ & Ultrasonic findings & $\begin{array}{l}\text { Radiographic } \\
\text { examinations }\end{array}$ & Final diagnosis & Comments \\
\hline 1 & $75 \mathrm{M}$ & $\begin{array}{l}\text { Tubular fluid collection } \\
\text { in thigh }\end{array}$ & $\begin{array}{l}\text { Plain radiography; } \\
\text { sinography }\end{array}$ & Abscess & $\begin{array}{l}\text { Patient had previous total hip } \\
\text { arthroplasty; surgically proven } \\
\text { when prosthesis removed }\end{array}$ \\
\hline 2 & $33 \mathrm{~F}$ & $\begin{array}{l}\text { Thigh fluid collection } \\
\text { with irregular margins }\end{array}$ & Plain radiography & Abscess & $\begin{array}{l}\text { Proven at ultrasonically guided } \\
\text { needle aspiration }\end{array}$ \\
\hline 3 & $53 \mathrm{M}$ & Calf fluid collection & $\begin{array}{l}\text { Plain radiography; } \\
\text { lower extremity } \\
\text { venography }\end{array}$ & Abscess & $\begin{array}{l}\text { Ultrasonically guided needle } \\
\text { aspiration }\end{array}$ \\
\hline 4 & $23 \mathrm{~F}$ & $\begin{array}{l}\text { Thigh fusiform fluid } \\
\text { collection }\end{array}$ & Plain radiography & Abscess & Surgically proven \\
\hline 5 & $44 \mathrm{~F}$ & Thigh fluid collection & $\begin{array}{l}\text { Plain radiography; } \\
\text { lower extremity } \\
\text { venography }\end{array}$ & Hematoma & $\begin{array}{l}\text { On anticoagulants for deep vein } \\
\text { thrombosis }\end{array}$ \\
\hline 6 & $25 \mathrm{M}$ & $\begin{array}{l}\text { Fluid collection with } \\
\text { well defined central } \\
\text { echogenic mass }\end{array}$ & Plain radiography & Hematoma & $\begin{array}{l}\text { Post-trauma; gradually resolved } \\
\text { without intervention }\end{array}$ \\
\hline 7 & $34 \mathrm{~F}$ & $\begin{array}{l}\text { Irregular mass with } \\
\text { some internal echoes }\end{array}$ & $\begin{array}{l}\text { Plain radiography; } \\
\text { angiography }\end{array}$ & Hematoma & $\begin{array}{l}\text { Syringomyelia with neuropathic } \\
\text { shoulder; surgically proven }\end{array}$ \\
\hline 8 & $59 \mathrm{M}$ & Calf fluid collection & $\begin{array}{l}\text { Lower extremity } \\
\text { venography }\end{array}$ & Hematoma & $\begin{array}{l}\text { Anticoagulated for deep vein } \\
\text { thrombosis; surgically proven }\end{array}$ \\
\hline 9 & $56 \mathrm{~F}$ & $\begin{array}{l}\text { Popliteal fluid } \\
\text { collection }\end{array}$ & $\begin{array}{l}\text { Plain radiography; } \\
\text { venography }\end{array}$ & Popliteal cyst & $\begin{array}{l}\text { Rheumatoid arthritis; } \\
\text { cyst aspirated }\end{array}$ \\
\hline 10 & $61 \mathrm{~F}$ & $\begin{array}{l}\text { Popliteal fluid } \\
\text { collection }\end{array}$ & Plain radiography & Popliteal cyst & No surgical or arthrographic proof \\
\hline 11 & $36 \mathrm{~F}$ & $\begin{array}{l}\text { Fluid collection } \\
\text { lateral calf }\end{array}$ & $\begin{array}{l}\text { Plain radiography; } \\
\text { arthrography }\end{array}$ & Synovial cyst & $\begin{array}{l}\text { ? rheumatoid arthritis; arthro- } \\
\text { graphically and surgically proven }\end{array}$ \\
\hline 12 & $39 \mathrm{M}$ & $\begin{array}{l}\text { Axillary septated } \\
\text { fluid collection }\end{array}$ & $\begin{array}{l}\text { Plain radiography; } \\
\text { sinography }\end{array}$ & Lymphocele & $\begin{array}{l}\text { Prior axillary node dissection for } \\
\text { melanoma. Surgically proven }\end{array}$ \\
\hline 13 & $66 \mathrm{~F}$ & Solid mass of arm & Plain radiography & Lipoma & Surgically removed \\
\hline 14 & $66 \mathrm{M}$ & Solid mass of thigh & Plain radiography & Metastatic sarcoma & Primary lesion in chest wall \\
\hline 15 & $56 \mathrm{M}$ & $\begin{array}{l}\text { Solid soft tissue } \\
\text { mass with bone erosion }\end{array}$ & $\begin{array}{l}\text { Plain radiography; } \\
\text { angiography }\end{array}$ & Osteosarcoma & Surgically proven \\
\hline 16 & $35 \mathrm{M}$ & Soft tissue mass of arm & Plain radiography & $\begin{array}{l}\text { Non-Hodgkin } \\
\text { lymphoma }\end{array}$ & Biopsy proven \\
\hline 17 & $76 \mathrm{M}$ & Popliteal aneurysm & $\begin{array}{l}\text { Plain radiography; } \\
\text { angiography }\end{array}$ & $\begin{array}{l}\text { Thrombosed } \\
\text { popliteal aneurysm }\end{array}$ & $\begin{array}{l}\text { Arteriogram showed narrowed } \\
\text { lumen. Surgically bypassed }\end{array}$ \\
\hline 18 & $50 \mathrm{~F}$ & Calf fluid collection & Angiography & Calf aneurysm & $\begin{array}{l}\text { Rheumatic fever and subacute } \\
\text { bacterial endocarditis; } \\
\text { had previous septic emboli }\end{array}$ \\
\hline
\end{tabular}

the diagnosis of hematoma, eliminated the need for additional venography in anticoagulated patients.

3. Synovial Cysts. Ultrasonography determined the presence of popliteal cysts in three patients (Fig. 4). Although this has previously been described $[2,6]$, one of four cases was unusual in that the cyst arose from the tibiofibular joint (Fig. 5). The cystic nature of the lesion on ultrasonography contradicted the physical examination, on which the mass was very firm and was thought to represent a solid tumor.
In this case, arthrography and ultrasonography confirmed the diagnosis (Fig. 5).

4. Lymphocele. One patient developed a septated axillary lymphocele (Fig. 6) as a complication of axillary node dissection for malignant melanoma.

\section{Solid Masses}

1. Benign Tumor. In one patient, ultrasonography demonstrated a homogeneous mass in the arm, which 

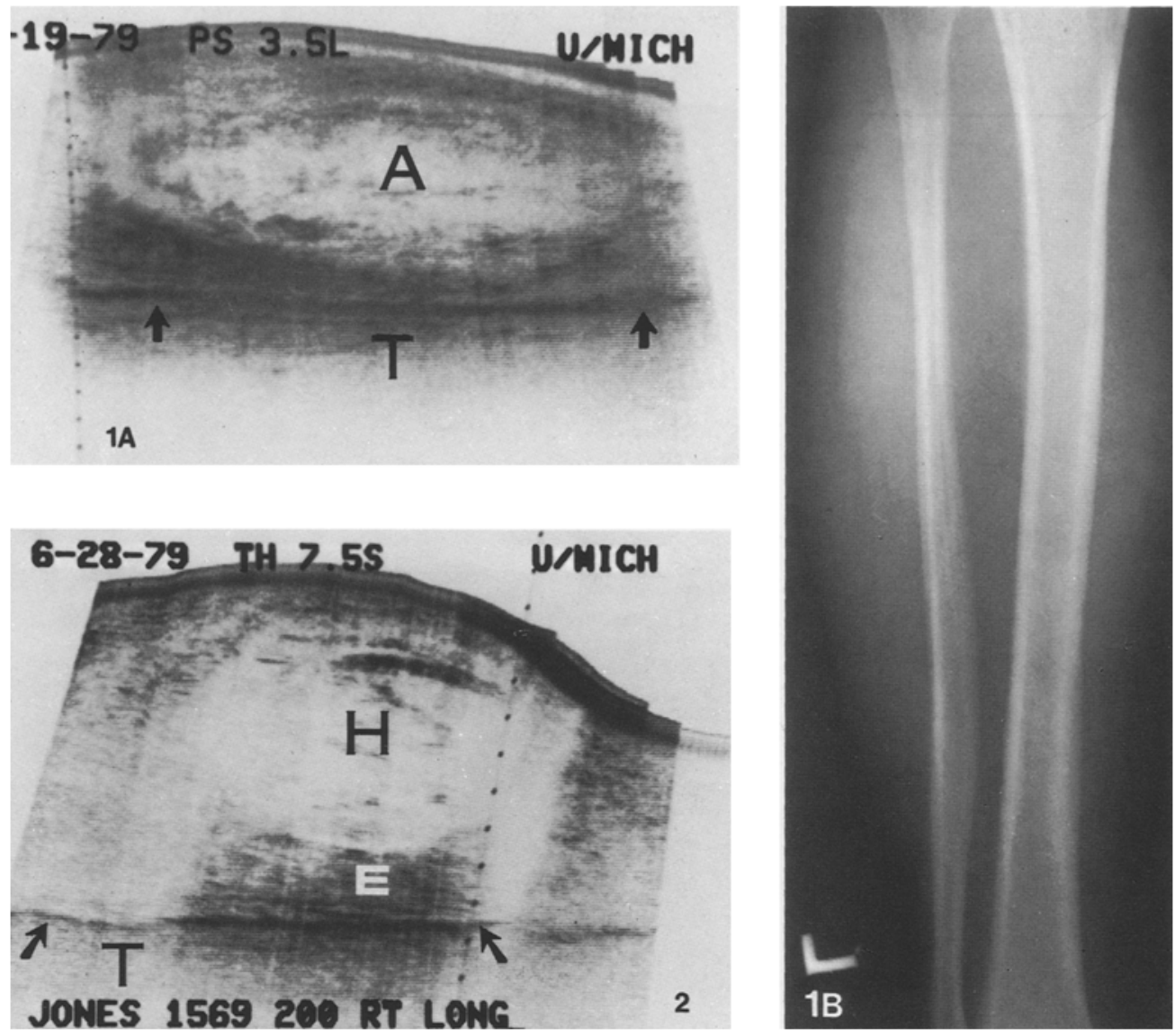

Fig. $1 \mathrm{~A}$ and B. Case 3. Abscess. 53-year-old diabetic man with calf pain and swelling. A Sagittal scan through posterior aspect of lower extremity showing irregular sonolucent mass $(A)$ with internal echoes of varying intensity. Percutaneous aspiration under ultrasonic guidance was diagnostic. Arrows point to posterior cortex of tibia $(T)$. B Anteroposterior radiograph demonstrates mild soft tissue swelling of calf

Fig. 2. Case 8. Hematoma. 58-year-old man on warfarin with calf pain and swelling. Sagittal scan with $7.5 \mathrm{MHz}$ (short internal focus) transducer shows ovoid, hypoechoic mass $(H)$ with enhanced through transmission and scattered internal echoes. Arrows point to posterior cortex of tibia $(T)$
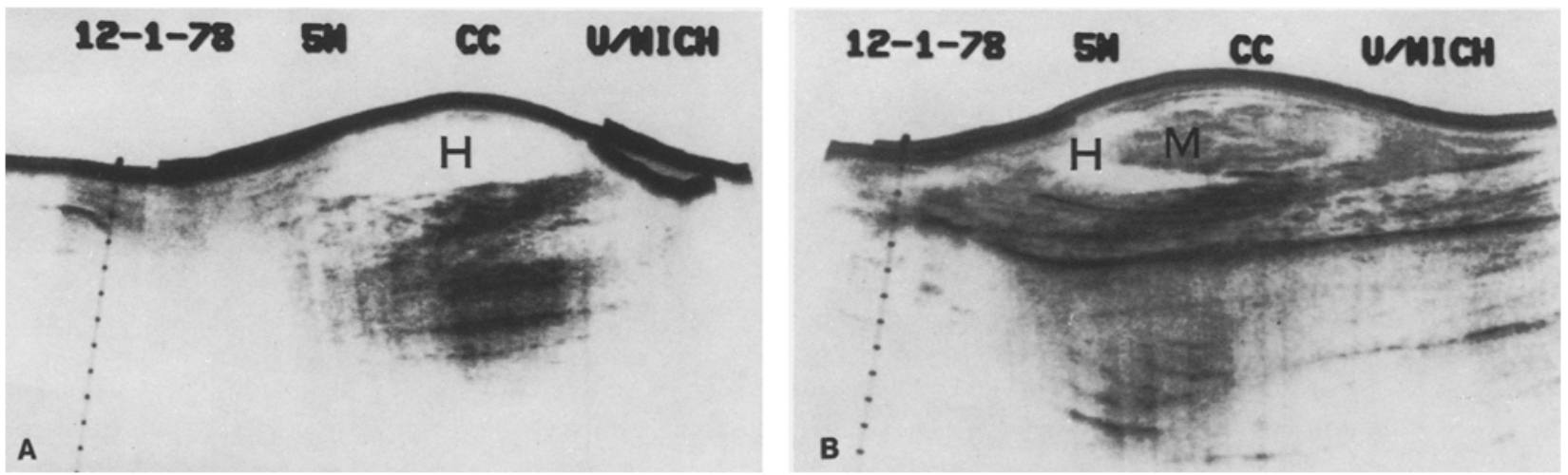

Fig. $3 \mathrm{~A}$ and B. Case 6. Hematoma. 25-year-old woman with severe posttraumatic calf pain and swelling. A Sagittal scan showing well demarcated echo-free mass with enhanced through transmission. B Sagittal scan $2 \mathrm{~cm}$ medial to A showing fluid $(H)$ surrounding gastrocnemius muscle $(M)$. Scans were obtained with $5 \mathrm{MHz}$ transducer 


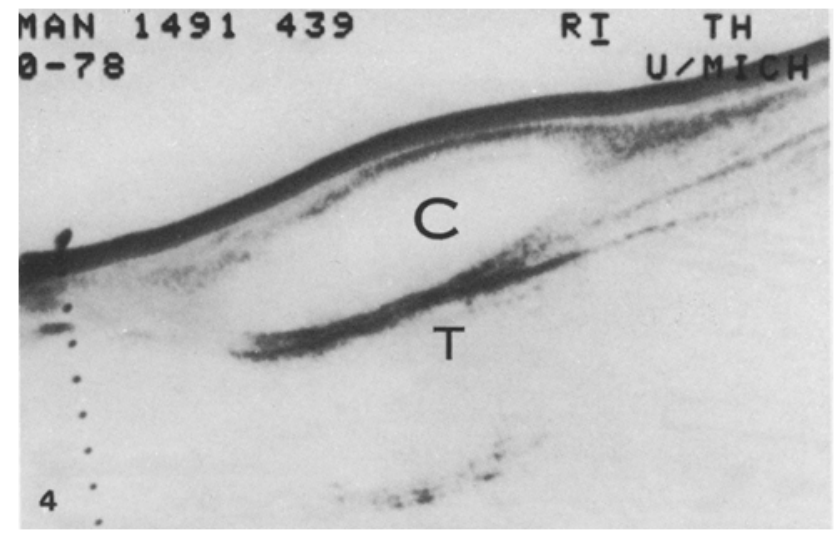

Fig. 4. Case 10. Popliteal cyst. 62-year-old woman with rheumatoid arthritis and painful swelling in popliteal space. Sagittal scan shows echo-free mass $(C)$ with sharp margins extending caudally from popliteal crease. (cm markers). $T=$ Tibia

Fig. $5 \mathrm{~A}$ and B. Case 11. Synovial cyst. 35-year-old woman with rheumatoid arthritis and proximal calf swelling. On physical examination the mass was hard and thought to represent a tumor. A Sagittal oblique scan showing sonolucent mass inferolateral to popliteal space. B Contrast material injected into knee joint extends through the tibiofibular joint rather than a popliteal bursa (white arrow)
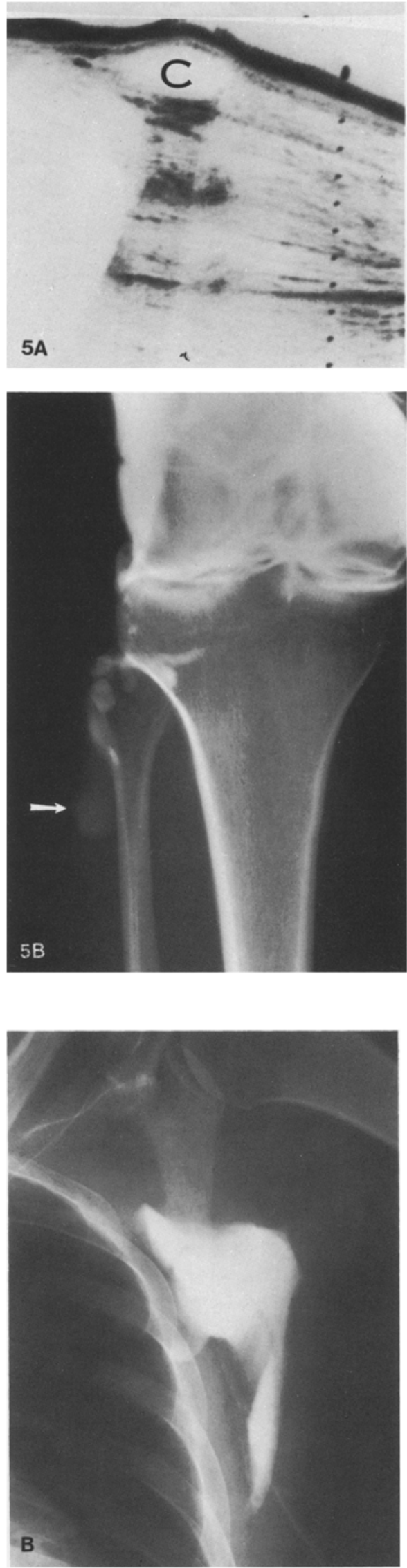

Fig. 6 A and B. Case 12. Lymphocele. 39-year-old man with malignant melanoma, status post-axillary lymph node dissection. A Sagittal scan through axilla showing multilocular fluid filled mass with enhanced sound transmission. Septations (arrowheads) are not as evident on contrast examination (Fig. $8 \mathrm{~B}$ ). $C=$ chest wall. B Sinogram demonstrating cystic axillary mass with extension along chest wall 


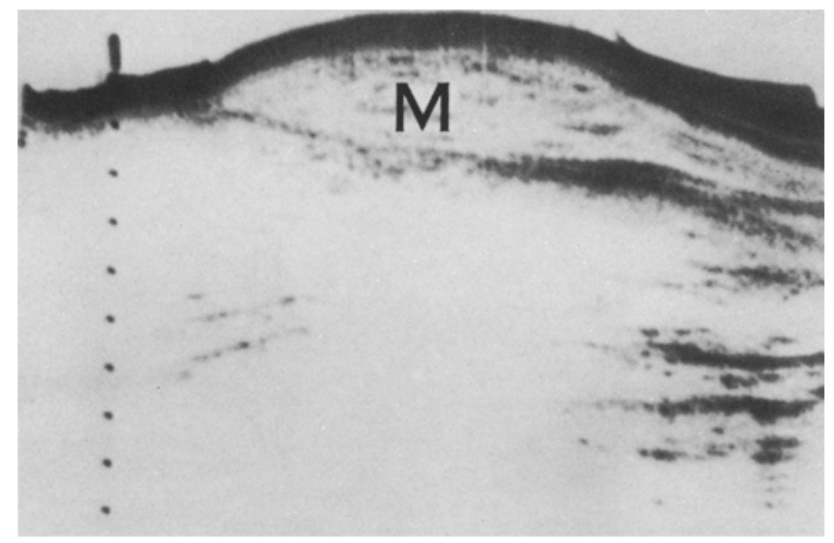

Fig. 7. Case 13. Lipoma. 66-year-old woman with soft tissue mass of arm. Sagittal scan showing $9 \mathrm{~cm}$ solid mass (M) adjacent to humerus. The extent of this mass was not appreciated radiographically
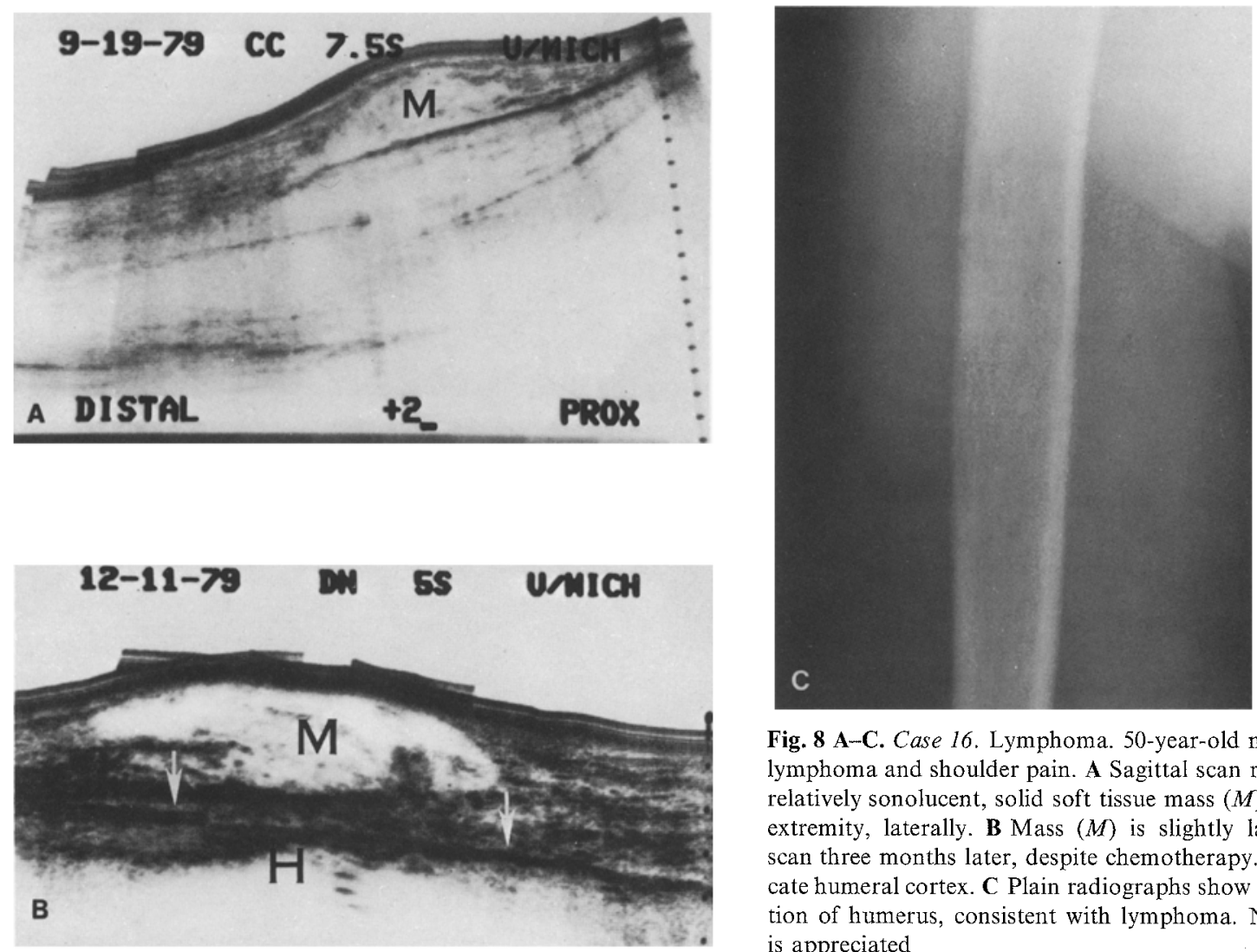

Fig. 8 A-C. Case 16. Lymphoma. 50-year-old man with histiocytic lymphoma and shoulder pain. A Sagittal scan reveals unsuspected, relatively sonolucent, solid soft tissue mass $(M)$ in proximal upper extremity, laterally. B Mass $(M)$ is slightly larger on follow-up scan three months later, despite chemotherapy. White arrows indicate humeral cortex. C Plain radiographs show permeative destruction of humerus, consistent with lymphoma. No soft tissue mass is appreciated
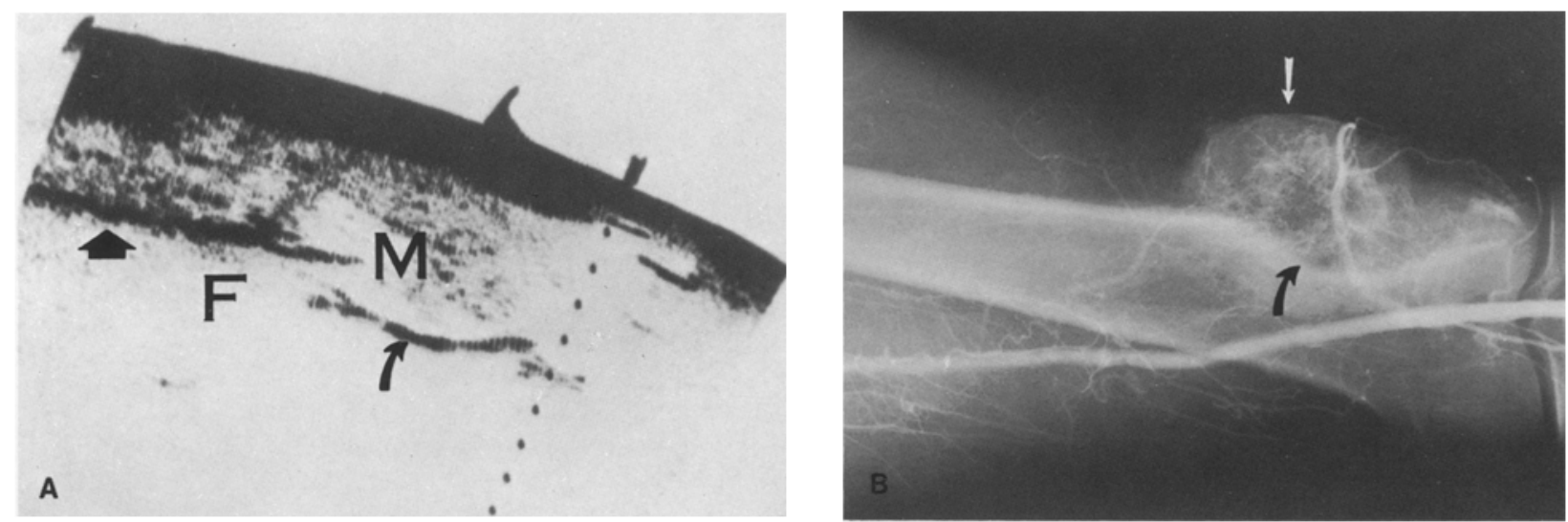

Fig. 9 A and B. Case 15. Osteosarcoma. 56-year-old man with swollen right knee. A Sagittal scan immediately proximal to right knee shows soft tissue mass $(M)$ and bone destruction (curved arrow). Broad arrow points to normal cortical surface of femur ( $F$ ). B Angiogram shows large soft tissue mass (white arrow) and bone destruction (curved arrow) corresponding to features seen ultrasonographically in A. Plain radiographs did not show soft tissue mass. This figure is displayed in same projection on sonogram of $\mathbf{A}$ 


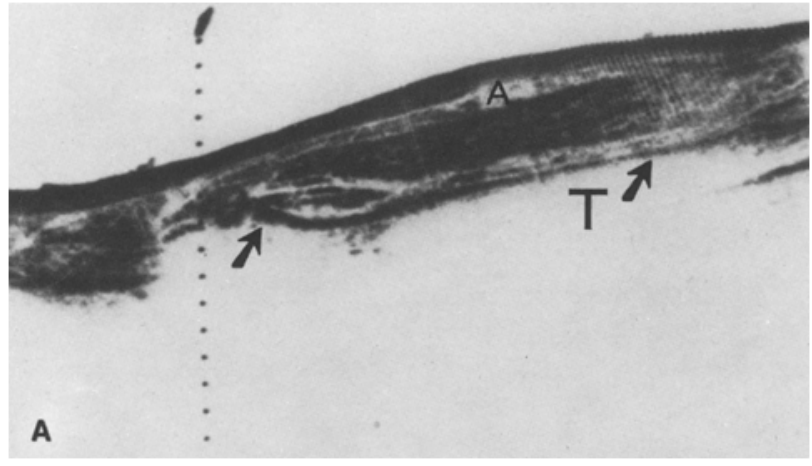

Fig. $10 \mathrm{~A}$ and B. Case 18, Peripheral aneurysm. 49-year-old woman with history of rheumatic fever and endocarditis presented with sudden calf pain, pulsatile mass, and initially absent distal pulses which subsequently returned. A Sagittal scan through lower extremity shows $2 \mathrm{~cm}$ fluid collection $(A)$ which appeared connected to calf vessel. Arrows indicate tibial cortex. B Arteriogram demonstrates small aneurysm in location corresponding to that on ultrasonography (white arrow)

at surgical exploration proved to be a lipoma (Fig. 7). Although the mass was $9 \mathrm{~cm}$ in its longest diameter, it was not visible on plain radiographs (Fig. 7). However, radiographs using the soft tissue technique were not obtained.

2. Malignant Tumors. The other three patients with solid masses demonstrated ultrasonographically were shown to have malignant tumors. In two of these, plain radiographs showed bone destruction but ultrasonography showed significant soft tissue masses, as well (Figs. 8 and 9). The extent of these masses was not appreciated on plain radiography (Figs. 8 and 9). Angiography, however, showed the soft tissue component in one case (Fig. 9).

\section{Vascular Lesions}

1. Aneurysms. Ultrasonic diagnosis of popliteal aneurysms is well known [8]. In one of our patients with subacute bacterial endocarditis and painful calf swelling, ultrasonography showed a one centimeter aneurysm in the distal calf which subsequently was confirmed angiographically (Fig. 10). Ultrasonography of the other patient showed a thrombosed popliteal aneurysm not opacified on angiography.

\section{Discussion}

Fluid collections in the extremities have similar ultrasonic characteristics as those elsewhere in the body,

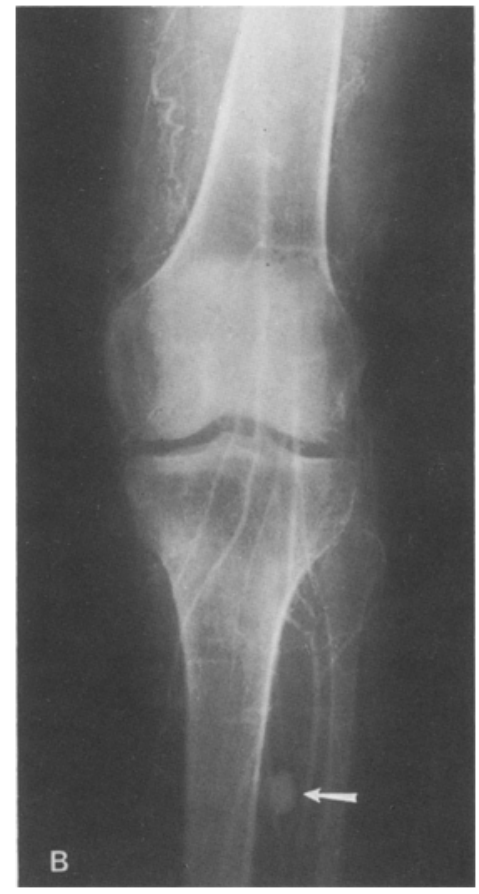

although they may be more confined by muscular and fascial planes. Abscesses are typically irregular, relatively anechoic masses with variable amounts of internal echoes due to debris. Our experience indicates that ultrasonically guided percutaneous needle aspiration of extremity masses is useful and may preclude the need for further diagnostic evaluation. Appropriate antibiotic therapy may be instituted on the basis of culture and sensitivity of the infecting organism.

The ultrasonic diagnosis of hematoma assumes a particularly important role in the anticoagulated patient. Although the sonographic characteristics may resemble those of an abscess or solid mass depending upon the age of the hematoma [9], the clinical setting contributes to the correct diagnosis.

In anticoagulated patients, there may be clinical confusion between hematoma and progressive deep vein thrombosis unresponsive to therapy. Ultrasonographic visualization of a hematoma may yield a diagnosis without resorting to venography. The extent of dissection of a hematoma may be determined, in addition (Fig. 3).

In the diagnosis of popliteal cyst, ultrasonography is important but has not supplanted arthrography [3]. Its primary role is in distinguishing popliteal cysts from other lesions clinically simulating them, such as thrombophlebitis, aneurysm, or solid mass $[1,5]$. In our case of a cyst arising from the tibiofibular joint which communicated with the knee, ultrasonog- 
raphy clearly demonstrated the cystic nature and extent of the lesion.

Ultrasonography also proved to be of some value in the evaluation of solid masses. Normal bony structures can be demonstrated [7], as in one of our cases, both bone destruction and a soft tissue mass were appreciated (Fig. 8). Ultrasonography differentiated solid masses from fluid collections, and also delineated soft tissue extension. Nonetheless, computed tomography appears superior in evaluating bone tumors and their soft tissue extent [10]. Ultrasonography can noninvasively assess tumor response to therapy (Fig. 8).

Extremity aneurysms are easily evaluated by ultrasonography. Accurate measurement of size, definition of the outer wall, and presence of thrombus are more readily appreciated by ultrasonography than by angiography [8]. In certain clinical settings, such as subacute bacterial endocarditis, ultrasonography is the diagnostic method of choice. Its flexibility makes it suitable for evaluation of aneurysms or post-traumatic pseudoaneurysms of smaller, more peripheral arteries, as well.

Ultrasonography is a valuable modality to diagnose soft tissue masses of the extremities. It may clarify equivocal findings on plain radiographs or detect findings absent on plain radiographs. Occasionally, it yields a specific diagnosis, especially when interpreted in conjunction with clinical data. Ultrasonography may circumvent more invasive procedures, and in this regard can be particularly valuable in evaluating debilitated patients.

\section{References}

1. Carpenter, J., Hattery, R., Hunder, G., Bryan, R., McLeod, R.: Ultrasound evaluation of the popliteal space: Comparison with arthrography and physical examination. Mayo Clin. Proc. 51, 498 (1976)

2. Cooperberg, P., Tsang, I., Truelove, L., Knickerbocker, J.: Gray scale ultrasound in the evaluation of rheumatoid arthritis of the knee. Radiology 126, 759 (1978)

3. Gompels, B., Darlington, L.: Gray scale ultrasonography and arthrography in evaluation of popliteal cysts. Clin. Radiol. 30, $539(1979)$

4. Lawson, T., Mittler, S.: Ultrasonic evaluation of extremity soft tissue lesions with arthrographic correlation. J. Can. Assoc. Radiol. 29, 58 (1978)

5. McDonald, D., Leopold, G.: Ultrasound B-scanning in the differentiation of Baker's cyst and thrombophlebitis. Br. J. Radiol. 45, 729 (1972)

6. Moore, C., Sarti, D., Louie, J.: Ultrasonographic demonstration of popliteal cysts in rheumatoid arthritis. Arthritis Rheum. 18, 577 (1975)

7. Seltzer, S., Finberg, H., Weissman, B.: Arthrosonography-ultrasound examination of joints (abs). Invest. Radiol. 14, 373 (1979)

8. Silver, T., Washburn, R., Stanley, J., Gross, W.: Gray scale ultrasound evaluation of popliteal artery aneurysms. Am. J. Roentgenol. 129, 1003 (1977)

9. Wicks, J., Silver, T., Bree, R.: Gray scale features of hematomas: An ultrasonic spectrum. Am. J. Roentgenol. 131, 977 (1978)

10. Wilson, J., Korobkin, M., Genant, H., Bovill, E.: Computed tomography of musculoskeletal disorders. Am. J. Roentgenol. 131, 55 (1978) 